\title{
HATUHAHA AMARIMA LOU NUSA DALAM PERSPEKTIF FILSAFAT KEBUDAYAAN CORNELIS ANTHONIE VAN PEURSEN DAN RELEVANSINYA DENGAN KEUTUHAN BANGSA INDONESIA
}

\section{Jannes Alexander Uhi}

Badan Penelitian dan Pengembangan Gereja Protestan Maluku

Email: jannesuhi@gmail.com

\section{Sri Soeprapto}

Fakultas Filsafat Universitas Gadjah Mada

\section{Mukhtasar Syamsuddin}

Fakultas Filsafat Universitas Gadjah Mada

\section{Abstrak}

Hatuhaha Amarima Lou Nusa merupakan kelompok masyarakat adat yang memiliki kekhasan budaya sejak leluhur hingga zaman kontemporer. Kandungan nilai-nilai budaya Hatuhaha Amarima menjadi penting untuk diterapkan dalam konteks kehidupan keseharian masyarakat Hatuhaha Amarima Lou Nusa secara khusus maupun Indonesia secara umum. Tulisan ini bertujuan mengungkapkan dinamika historis dan wujud kebudayaan Hatuhaha Amarima, dan menggali hakikat Hatuhaha Amarima beserta nilai-nilai yang terkandung di dalamnya dengan menggunakan pemikiran filsafat kebudayaan Cornelis Anthonie van Peursen. Hakikat Hatuhaha Amarima, terdiri dari masyarakat, sejarah, wilayah, adat dan budaya, serta bahasa. Penelitian ini juga berhasil menjelaskan aspek epistemologi Hatuhaha Amarima yang sifatnya realis. Penelitian ini menemukan suatu polarisasi budaya Hatuhaha Amarima yang bersifat monodualisme, sehingga menghadirkan nuansa hidup bersama dalam suasana multikulturalisme; suku, agama, dan budaya. Salah satu pokok terpenting dari kepercayaan dan kebudayaan yang diteruskan oleh masyarakat Hatuhaha Amarima adalah relasi "aku" - "engkau" yang hadir dalam lingkup sistem kekerabatan, kekeluargaan, dan persaudaraan. Nilai-nilai budaya Hatuhaha Amarima ternyata berkaitan dengan prinsip Bhinneka Tunggal Ika, sehingga penting untuk diterapkan di dalam konteks keutuhan kehidupan berbangsa dan bernegara di Indonesia. Jiwa dari nilai Hatuhaha Amarima mere- 
54 Jurnal Filsafat, Vol. 26, No. 1, Februari 2016

presentasikan nilai-nilai idiil dari Pancasila dan nilai-nilai universal.

Kata Kunci: filsafat kebudayaan, budaya Hatuhaha Amarima, nilai budaya, keutuhan bangsa.

Abstract

Hatuhaha Amarima Lou Nusa refers to an indigenous group that has a specific culture from ancestors to contemporary times. The content of cultural values of Hatuhaha Amarima is important to be applied to the context of the daily lives of Hatuhaha Amarima Lou Nusa's people in particular and Indonesia in general. This paper aims to reveal the dynamics of historical and cultural forms of Hatuhaha Amarima, and to explore the nature of Hatuhaha Amarima, along with the values which contained in it with Cornelis Anthonie van Peursen's philosophy of culture perspective. The essence of Hatuhaha Amarima are contained with society (human), history, territory, customs and culture, and language. As the result, the study explaints the epistemologycal aspect of Hatuhaha Amarima in its realistic nature. Also, the study finds a cultural polarization of Hatuhaha Amarima that is as monodualistic in its nature, so it is presenting the feel of living together in multiculturalism with relative condition; ethnicity, religion, and culture. One of the most important point of culture that was passed on by people of Hatuhaha Amarima is the relation of I - You. This is existing in the context of kinship systems, family systems and brotherhood. Obviously, the cultural values of Hatuhaha Amarima has tighted connection with Bhineka Tunggal Ika's principles, so that it is important to applicate it to the context of the state living integrity and nation in Indonesia. The soul of cultural values of Hatuhaha Amarima represented of the ideal values of Pancasila and universal values.

Keywords: philosophy of culture, culture of Hatuhaha Amarima, cultural values, the integrity of nation.

\section{PENDAHULUAN}

Konflik antarwarga sering terjadi di Maluku, entah dalam skala kecil maupun besar. Konflik tidak saja terjadi antarpribadi, antargolongan, antaragama, bahkan juga antarsuku. Geososial Maluku yang berbasis kepulauan, dan karenanya disebut "Daerah Seribu Pulau" dengan ribuan kategori sosial-budaya kemasyarakatannya, menampilkan adanya sebuah kondisi obyektif, yaitu perbedaan dan 
kemajemukan ciri sosial, budaya dan keagamaan yang berbasis komunitas kepulauan. Perbedaan tersebut selalu mengandung potensi konflik dan damai, juga cenderung menampilkan adanya prasangka (prejudice) dan gambaran buruk (streotipe) terhadap sesama lainnya sehingga, pada gilirannya akan menjadi pemicu konfik, baik yang bersifat antarwarga, antaretnik maupun antaragama.

Realitas konflik begitu menonjol sejak zaman prahistoris, yang kemudian telah membimbing masyarakat memasuki sebuah ambang kesadaran peradaban baru (new civilization) sebagai orang Maluku. Kesadaran peradaban baru tersebut yaitu budaya orang basudara (budaya orang bersaudara) dengan sebuah pola kehidupan adat yang kuat.

Kesadaran peradaban baru terjadi ketika perhatian dan pertimbangan untuk kembali ke bentuk tradisional kehidupan sosial yang ditinggalkan atau dihancurkan oleh modernisasi terlihat di zaman post-modern, yang akan memperlihatkan adanya pertimbangan untuk membangun kembali komunitas, pemakaian kembali ikatan sosial primordial, menghidupkan kembali kelompok dan hubungan primer (Sztompka, 2008: 96). Budaya hidup tersebut ditata dan dikelola, serta diselenggarakan dengan sebuah falsafah yang khas Maluku, yaitu falsafah hidop orang basudara (hidup orang bersaudara), sebagai bentuk kearifan lokal (local genius) anak negeri Maluku yang sarat dengan kekayaan nilai-nilai kehidupan, sehingga mempertautkan dan mempersatukan masyarakat Maluku di dalam realitas perbedaannya yang kaya. Salah satu wujud empirisnya pada budaya pela-gandong. Berbagai ritus adat selalu digelar secara rutin untuk proses pelestarian budaya hidup orang basudara tersebut, seperti: ritus panas pela, dan panas gandong (Watloly, 2012: 241-268).

Kearifan lokal menjadi ciri khas masyarakat yang berbudaya, dan masih menjaga kelestarian nilai-nilai luhur budayanya. Ciri khas masyarakat berbudaya dapat terlihat pada kehidupan anggota masyarakatnya, sehingga nampak pola hidup yang lahir dari pemahaman akan nilai-nilai budaya dalam kehidupan masyarakat setempat. Salah satu kearifan lokal di Maluku adalah uli (kelompok) Hatuhaha Amarima Lou Nusa (lebih dikenal dan selanjutnya disebutkan dengan nama 
Hatuhaha Amarima), yakni suatu kelompok masyarakat adat yang terletak di sebelah Utara pulau Haruku, Kecamatan pulau Haruku Kabupaten Maluku Tengah, Provinsi Maluku. Masyarakat Hatuhaha Amarima menjalani hidup dalam kemajemukan keyakinan, tetapi tetap melestarikan ciri-ciri pribadi Hatuhaha Amarima. Masyarakat Hatuhaha Amarima tetap dalam ikatan sebagai masyarakat adat. Pengaruh berbagai agama baru tidak membuat berubahnya hubungan kekerabatan dan persaudaraan, justru menjadikan Hatuhaha Amarima tetap dalam keutuhan dengan tradisi hidup (budaya dan adat) yang tetap kokoh. Keutuhan masyarakat tetap terjadi meskipun Islam dianut oleh keempat negeri (Pelauw, Rohomoni, Kabauw dan Kailolo) dan Kristen dianut oleh negeri Hulaliu. Kenyataan suasana persaudaraan dalam kehidupan masyarakat Hatuhaha Amarima yang berlangsung pada setiap tahap perkembangan kebudayaan yang ada di komunitas Hatuhaha Amarima mendorong penulis untuk mengaji Hatuhaha Amarima dengan menitikberatkan kajian ini pada upaya mengungkap dinamika historis dan wujud kebudayaan Hatuhaha Amarima, serta menemukan hakikat Hatuhaha Amarima. Telaah atas Hatuhaha Amarima dilakukan dalam perspektif filsafat kebudayaan melalui pemikiran Cornelis Anthonie van Peursen untuk menemukan makna dan nilai-nilai budaya yang terkandung di dalamnya. Penelitian ini dilakukan juga untuk menemukan relevansinya dengan keutuhan bangsa Indonesia.

\section{KONSEP KEBUDAYAAN DALAM FILSAFAT KEBUDAYAAN C.A. VAN PEURSEN}

Van Peursen (2003: 130) berpendapat, istilah culture (budaya) memiliki arti yang lain sama sekali. Kebudayaan itu ibarat sebuah cerita yang belum tamat, yang masih harus disambung, sehingga kebudayaan dilukiskan sebagai suatu tahap, atau bagian dalam cerita sejarah tentang perkembangan manusia. Konsep budaya yang dijelaskan van Peursen menegaskan bahwa kebudayaan bukanlah sesuatu yang ada di waktu lampau, atau yang ada di luar manusia. Kebudayaan meliputi hakikat perbuatan manusia itu sendiri, sehingga berbicara tentang 
kebudayaan berarti berbicara tentang manusia dan masa depan manusiaitu sendiri.

Manusia harus berusaha memanusiakan dirinya melalui kebudayaan. Van Peursen (1988: 11) menjelaskan, konsep kebudayaan dalam pandangan sebagai hal yang dinamis, bukan sesuatu yang kaku atau statis, sebagaimana yang dikonsepkan pada waktu lampau. Intinya, kebudayaan adalah sebagian dari kemanusiaan manusia. Manusia baru akan menemukan kebudayaan, apabila manusia melihat dunia ini dalam sorotan rencana keberadaan manusia. Suatu kebudayaan membuat sebuah gambaran dari dunia secara tertentu, sehingga dunia di dalam gambaran kebudayaan tertentu juga memperoleh corak yang khas (van Peursen, 1975: 24). Van Peursen menyebutnya dengan istilah cultural context (konteks kebudayaan), yakni yang memengaruhi pengetahuan manusia tentang dunia luar. Alam raya, bagi manusia, bukanlah suatu data yang pasti dan yang tidak berubah. Alam itu dibatasi dan dipatoki menurut suatu lingkungan kebudayaan tertentu atau sebuah visi kebudayaan tertentu. Filsafat kebudayaan menampilkan hakikat kebudayaan sebagai suatu perjuangan manusia melampaui keberadaannya sebagai manusia. Artinya, dalam melihat hakikat kebudayaan akan ditemukan istilah yang tidak asing lagi, yaitu "makna eksistensi manusia". Van Peursen (1988: 178) melihatnya sebagai suatu kerangka acuan yang menyeluruh bagi fenomen yang tidak mungkin berdiri sendiri. Fenomen-fenomen serupa itu harus dilihat dalam kaitan dengan manusia yang berorientasi, dan dalam hal ini dapat mengatakan "aku" yang memberitahukan perbuatan serta maksud-maksud tertentu. Fenomenologi tentang "aku" yang berisikan elemen-elemen terstruktur dalam diri manusia, seperti "orientasi", "roh", dan "aku" menunjukkan struktur manusia yang menyeluruh.

Van Peursen (2003: 124) menjelaskan bahwa umumnya konsep kebudayaan sering mengingatkan orang pada sesuatu yang khas, sesuatu yang tidak termasuk hal-hal sesehari. Kebudayaan sebenarnya menyangkut manusia itu sendiri. Kebudayaan adalah hak cipta manusia. Kebudayaan baru ada dan berfungsi jika berada di dalam jangkauan manusia. Kebudayaan dapat bermakna apabila dilihat dalam eksisten- 
si dan rencana hidup manusia. Kebudayaan, dengan sendirinya, dapat terjadi dan berkembang karena dorongan hidup yang terus mendesak. Artinya, melalui kebudayaan manusia dapat memanfaatkan materi yang ada di sekitarnya. Materi, pada awalnya, memang dapat membatasi berbagai kemungkinan rohani, namun pembatasan ini cukup berguna. Pembatasan itu memungkinkan terkonsentrasinya manusia pada suatu tujuan dan arah yang telah digariskan terlebih dahulu secara seksama, sehingga materi menjadi tonggak-tonggak utama untuk melompati hal vital tersebut.

Landasan ontologis kebudayaan yang dikembangkan oleh van Peursen lebih terfokus pada pemakaian istilah "substansi". Van Peursen (1980: 73) mengungkapkan, dalam pergaulan sehari-hari istilah "substansi" kadang-kadang dipakai dalam arti "materi" atau "inti pati". Substansi berarti hakikat kenyataan yang menopang segala gejala, dan yang tidak berakar lagi dalam suatu lapisan kenyataan yang lebih mendalam. Kata substansi yang berarti sesuatu yang dapat berdiri sendiri, mempunyai landasan sendiri, dan tidak perlu bersandar pada sesuatu di luarnya (van Peursen, 1988:76). Adapun substansialisme dimaksudkan sebagai sikap yang sesungguhnya ingin menempatkan barang-barang lepas antara yang satu dari lainnya, tidak tergantung lagi dari sesuatu di luarnya. Konsep substansi memaparkan kekayaan dunia konkrit yang tak pernah usai, atau pengamatan manusia yang konkrit tidak terungkapkan. Artinya, segala pemikiran manusia tentang substansi itu mendorong manusia untuk mengerti dengan lebih mendalam mengenai bahasa benda-benda.

Pandangan van Peursen bahwa manusia merupakan makhluk hidup yang dalam realitasnya selalu dinamis. Manusia bukan saja memiliki "ada" berupa fakta diri yang fisik biologis apa adanya, tetapi juga memiliki dinamika keber-ada-an berupa peristiwa eksistensi yang hakiki. Substansi terdalam dari manusia adalah tubuh dan jiwa, yang tidak dapat dicari unsur substansialnya. Menurut van Peursen (tth: 150), hal itu dapat dipandang dalam dua macam kedudukan, yakni: 1) sebagai subjek dalam kalimat, atau "aku" yang sedang melakukan kegiatan; 2) sebagai tubuh dan jiwa. Ada pertentangan antara tubuh 
atau badan dan jiwa, tetapi tidak secara eksklusif, melainkan merupakan suatu keadaan yang terdiri dari dua bidang saling berdempetan atau berjajaran.

Fenomenologi eksistensial terlihat pada landasan ontologis kebudayaan van Peursen, yakni manusia dan alam. Kebudayaan dilihat sebagai aktivitas manusia dalam keterhubungan dengan fenomena alam. Van Peursen (1988: 178-179) menyebutkan, manusia yang bereksistensi harus dipandang sebagai subjek perbuatan-perbuatan dan subjek orientasi, supaya roh dapat tampak sebagai pola tingkah laku yang menyeluruh. Alur eksistensi manusia, yang bersumber dari jiwa dan tubuh sebagai substansi yang mendasar dari manusia, memunculkan suatu makna eksistensi manusia, yang menempatkan kembali objektivasi-objektivasi (jiwa dan tubuh) ke dalam pola tingkah laku manusia yang konkrit. Jangkauannya sampai pada konteks suatu kebudayaan yang konkrit, sehingga kebudayaan seakan-akan merupakan bekas telapak manusia dalam dunianya. Kebudayaan, menurut van Peursen, justru jauh melebihi telapak manusia. Dunia diolah sehingga menjadi sebagian dari tingkah laku dan praksis manusia.

Dasar ontologi kebudayaan, menurut van Peursen, terlihat dengan jelas ketika substansialitas jiwa dan tubuh yang membuat adanya manusia dapat menghadapi tantangan hidup dalam berbagai ruang dan waktu untuk tetap bereksistensi, dan inilah yang selalu memunculkan kebudayaan. Ontologi van Peursen mengenai kebudayaan nampak dalam penjelasannya bahwa kebudayaan meliputi seluruh wilayah praksis manusia, yang berlangsung secara sadar maupun tidak sadar (van Peursen, 1988: 181). Kebudayaan tidak merupakan sampingan dari manusia, melainkan dalam proses budaya itu manusia menjadi manusiawi yang sesungguhnya. Kebudayaan manusia tersebut muncul sebagai pengungkapan roh, baik dalam aspek objektif maupun subjektif. Filsuf yang menaruh perhatian terhadap kebudayaan harus melihat epistemologi sebagai suatu pengetahuan yang melibatkan pancaindra dan akal budi (van Peursen,1980: 19).

Dua macam bentuk pengetahuan yang menjadi pusat perhatian van Peursen, yakni pengetahuan lewat pancaindra dan pengetahuan 
lewat akal budi. Kedua macam pengetahuan ini, dalam sejarah filsafat, saling dipertentangkan. Van Peursen setuju dengan pendekatan pengetahuan berdasarkan paham realisme, meskipun bagi van Peursen pendekatan tersebut belum dapat menghasilkan suatu pengetahuan yang benar, sehingga ada faktor lain yang turut mempengaruhi dan menjadikan hasil tangkapan indera dapat mencapai suatu kebenaran. Faktor lain tersebut adalah ratio, akal. Van Peursen (1972: 14) menekankan hal tersebut, dengan menyebutkan bahwa dalam filsafat juga reaksi emosional, realitas dapat memberikan atau membentuk sistemsistem dengan menggunakan logika. Diakui bahwa pengetahuan itu berawal dari sesuatu yang riil atau nyata pada pengalaman manusia. Manusia mengekspresikan hidup yang dialaminya secara alamiah melalui emosi. Pada bagian lain, Van Peursen mempertegas pendapatnya dengan menyebutkan bahwa manusia mengenal seluruh eksistensi yang meliputi tiga corak pengetahuan, yakni: akal, emosi, dan sikap praktis (van Peursen, 1987:4).

Van Peursen (1992: 557-558) juga berpendapat, pengetahuan tidak keluar dari akal budi (intelek) semata, melainkan dari intuisi. Artinya, intuisi bukanlah suatu perasaan irasional, tetapi suatu pengetahuan yang melihat secara menyeluruh, bukan melihat bagian-bagian tertentu. Van Peursen berpendapat bahwa ada faktor lain yang membuat pengamatan manusia, melalui pancaindra, menjadi suatu pengetahuan yang memiliki kebenaran, yaitu logika, yang dalam istilah Berkeley disebut ide. Manusia akan mencoba memahami realitas mulai dari dirinya. Epistemologi kebudayaan yang dibangun van Peursen (1972: 18) mengacu pada pemikiran tersebut, dan menyebutkan bahwa ada dua pendekatan yang dapat dilakukan ketika memahami suatu realitas budaya, yaitu: pertama, datang dari dunia atau alam secara eksternal, atau yang disebut dengan istilah "fenomena apa yang ada"; kedua, diproses dari diri sendiri. Realitas hanya dapat diketahui dan dipahami dalam hubungan dengan manusia. Manusia adalah manusia, hanya dengan dan melalui realitas, realitas manusia menjadi berarti. Hanya dengan dan melalui realitas, manusia dapat dihubungkan dengan struktur total dari realitas. 
Struktur total dari realitas tersebut adalah alam, manusia, dan kebudayaan. Konsep sistem nilai budaya yang ada mesti mempertimbangkan faktor yang menentukannya, yaitu fakta, sebagaimana yang ditegaskan oleh van Peursen (1990: 54) bahwa fakta memperoleh maknanya dalam percakapan yang bersifat intersubjektif. Artinya, fakta hanya dapat terlihat jelas dalam konteks masyarakat atau kebudayaan khusus. Fakta tidak dapat dipisahkan dari jenis bahasa yang mengacu kepada fakta tersebut, sehingga fakta hanya dapat terlihat dalam keragaman dan nuansa penggunaan bahasa, yakni pada perilaku manusia. Jelasnya, mengungkapkan fakta nampaknya merupakan persoalan objektivitas dan tentang pandangan yang netral saja. Hal ini berarti, fakta adalah titik temu dari serangkaian makna lebih fundamental, yang dapat dikenakan pada fakta-fakta itu. Menetapkan fakta maka hal itu hanya menunjuk kepada aspek-aspek dari suatu situasi menyeluruh. Artinya, dengan memisahkan aspek semacam ini, manusia akan memperoleh suatu fakta yang agak stabil dan objektif. Fakta yang terpisah seperti itu hanya merupakan aspek skematis dari realitas yang lebih luas, yang dilepaskan dari peran yang sebenarnya dimiliki dalam sejarah manusia. Artinya, fakta juga dilepaskan dari maknanya yang lebih luas di dalam situasi-situasi historis, sosial, etis, kultural, dan religius. Van Peursen (1990: 56) mengatakan bahwa realitas yang sebenarnya tidak dapat ditetapkan sebagai data-data murni, tanpa hubungan dengan suatu kebijaksanaan manusia. Artinya, fakta dalam pengertian pernyataan skematik (konstatatif), merupakan skematisasi yang lebih objektif, tetapi juga lebih abstrak dari faktualitas nyata. Hal ini berarti penilaian yang salah sering menimbulkan fakta yang salah, dan penilaian yang tepat sering menimbulkan fakta yang tepat. Tepat di sini, tidak dalam pengertian moral atau estetis baik, melainkan dalam arti benar secara deskriptif. Van Peursen (1990: 64-68) menekankan, mempertahankan suatu nilai tertentu lambat laun menjadi suatu aturan tingkah laku yang dapat dinilai sebagai berguna bagi masyarakat secara teratur. Penjelasan ini hendak menegaskan bahwa kadang fakta-fakta harus ditetapkan, sebab fakta hanya merupakan fosil nilai. Prinsip utama yang dimiliki van Peursen (1990: 81) adalah antara nilai dan nor- 
ma sama-sama mengacu kepada sesuatu yang menuntut ketaatan.

Aturan-aturan yang ada dalam masyarakat merupakan pedoman dan nasehat tentang bagaimana manusia taat kepada suatu kriteria tertentu. Makna terdalam dari pandangan ini menegaskan suatu kepatuhan manusia terhadap nilai-nilai (dan norma). Artinya, kebudayaan masyarakat merupakan suatu bukti adanya fakta yang terjadi dalam peristiwa. Fakta itu sendiri merupakan fosil dari nilai, sehingga dalam suatu masyarakat berbudaya nilai-nilai budaya mendapat tempat yang penting. Letak pendekatan van Peursen terhadap pemahaman nilai budaya, yang terlihat pada penjelasan ini, tidak lepas dari pengaruh fenomenologi eksistensial yang dianutnya. Van Peursen selalu melakukan kajian-kajian filsafatnya, termasuk uraian aksiologi, dari perspektif yang sama. Hal ini penting dalam menganalisis aspek-aspek filosofis pada Hatuhaha Amarima. Van Peursen menggarisbawahi perkembangan yang memperlihatkan aneka macam tahap dalam kebudayaan manusia. Tahap-tahap ini memperlihatkan adanya makna yang terkandung dalam setiap kebudayaan. Tahap-tahap yang dimaksudkan oleh van Peursen bertujuan membuka jalan, sehingga manusia mampu menilai perkembangan yang ada secara kritis. Adapun tahap-tahap perkembangan budaya yang dimaksudkan oleh van Peursen (1988: 18), yaitu: tahap mitis, ontologis, dan fungsionil. Pertama, tahap mitis, yaitu tahap ketika manusia memiliki sikap yang merasakan dirinya terkepung oleh kekuatan-kekuatan gaib sekitarnya. Manusia, pada dunia mitis, diliputi oleh alam kebudayaan "primitif", yakni manusia-manusia yang langsung berhubungan dengan daya-daya alam yang serba rahasia. Kedua, tahap ontologis, yakni tahap di mana manusia memiliki sikap yang tidak hidup lagi dalam kepungan kekuasaan mitis, melainkan secara bebas ingin meneliti segala fenomena yang terjadi di sekitarnya. Manusia mulai mengambil jarak terhadap segala sesuatu yang mengitarinya. Manusia berusaha memperoleh pengertian mengenai daya-daya kekuatan yang menggerakkan alam dan manusia (van Peursen, 1988: 55). Pada tahap ontologis, manusia mulai menanyakan tentang "apa"-nya para dewa. Manusia ingin menyelidiki alam, ingin tahu tentang "apa"-nya para dewa yang menghuni alam di 
atas kodrat manusia. Tahap ontologis hanya membuktikan bahwa telah terjadi pergeseran dalam cara berpikir. Manusia mulai melepaskan dirinya dari belenggu determinasi mitis yang membuatnya tidak bebas berkreasi. Ciri khas utama pada taraf ini adalah manusia mengakui, membela, dan mempertahankan haknya dari pengaruh luar (Veeger, 1985: 28), sehingga manusia mengelompokkan dirinya dalam satu kekuatan institusi sosial kemasyarakatan. Ketiga, tahap fungsional, yaitu tahap ketika manusia memiliki sikap dan alam pikiran yang makin nampak dalam manusia modern. Manusia tidak lagi terpesona dengan alam mitis, dan tidak lagi membuat jarak terhadap objek penyelidikannya. Manusia, dalam tahap ketiga mengadakan relasi-relasi baru, membuat suatu kebertautan yang baru terhadap segala sesuatu dalam lingkungannya. Tahap berpikir fungsional adalah taraf di mana manusia berhadapan dan mengadakan relasi-relasi baru. Manusia, pada taraf ini, mengalami kebertautan yang baru terhadap segala sesuatu dalam lingkungannya.

Tahap-tahap perkembangan budaya, yang disebutkan oleh van Peursen, menunjukkan adanya suatu dinamika dalam kehidupan manusia. Dinamika tersebut melahirkan suatu sikap manusia untuk selalu bergerak mengatasi setiap krisis yang dihadapi. Artinya, dinamika kehidupan manusia yang terus-menerus bergerak mengatasi tantangan hidup tersebut selalu melahirkan kebudayaan. Paham van Peursen tentang kebudayaan adalah dinamika manusia berbentuk "spiral", bergerak maju untuk mencapai tujuan hidup. Sikap manusia tidak saja berwujud dalam aktivitas atau perbuatan yang melahirkan budaya, namun juga menyangkut persepsi atau paham manusia dalam menyikapi alam dengan berbagai tantangan hidup yang dihadapi manusia. Sejarah manusia berhadapan dengan realitas-realitas dan mengalami kecenderungan untuk selalu memperbaiki kehidupan.

\section{DINAMIKA HISTORIS DAN WUJUD KEBUDAYAAN HATUHAHA AMARIMA}

Masyarakat Hatuhaha Amarima mengakui bahwa secara historis asalnya dari Nunusaku, yaitu sebuah gunung yang sakral dan suci. 
Tauern (1918: 205-207) menjelaskan Nunusaku dipercaya oleh orang Maluku, khususnya Seram, sebagai pusat bumi. Nunusaku tercipta bersamaan dengan munculnya pulau Seram dari dasar laut. Di Nunusaku terdapat sebuah pohon beringin yang sangat besar yang melahirkan manusia-manusia pertama yang kemudian menyebar ke seluruh pulau Seram. Nunusaku merupakan puncak gunung kosmik, yang tidak saja dilihat sebagai titik tinggi bumi, tetapi menjadi pusat dan titik dimulainya penciptaan manusia pertama (Alifuru).

Manusia Nunusaku atau yang sering disebut Alifuru, memang merupakan makhluk yang berpikir, sehingga Nunusaku merupakan awal peradaban dan sejarah Maluku. Nunusaku telah menjadi titik tolak pembahasan dan kajian tentang sejarah masyarakat dan kebudayaan Maluku. Alifuru (manusia pertama) Nunusaku terdiri dari dua rumpun (suku) besar, suku Alune dan Wemale, Masing-masing suku dipimpin oleh Upu Hena atau Upu Aman. Upu artinya "Yang Mulia" atau "Yang Dihormati", sedangkan Hena dan Aman artinya negeri atau perkampungan. Upu Hena atau Upu Aman berarti "Yang dihormati dalam negeri atau suku yang ada" (Ralahalu dan Lokollo, 2011:14).

Perang Wemale-Alune merupakan peristiwa bersejarah, dan menjadi cikal-bakal penyebaran penduduk Nunusaku ke berbagai daerah di Maluku. Pada saat itu, perang Wemale-Alune merupakan perang suku yang terbesar dan berdampak pada munculnya kelompok Patasiwa dan Patalima. Bartels (1994:38) menyebutkan, perang Wemale-Alune berawal dari kematian Rapie Hainuwele, putri dari Upu Aman Nunusaku atau disebut Kapitan Uralo (Kapitan Besar) yang bernama Tuwale. Pasca perang Wemale - Alune, penduduk Nunusaku melakukan migrasi, dan sebagian kelompok yang migrasi menemukan gunung Alaka dan menjadikannya tempat persinggahan. Selanjutnya, tempat tersebut menjadi tempat tinggal dan pusat kehidupan masyarakat Hatuhaha Amarima.

Sekelompok orang yang datang dari Nunusaku ke Alaka adalah orang-orang yang memiliki hubungan sebagai gandong (lahir dari satu keturunan). Kelompok tersebut merupakan keturunan Hamsasja (sultan van Alaka) yang memiliki anak "Latuconsina", dan cucu "Latu- 
rone". Laturone mempunyai lima orang anak, yaitu Latuconsina, Laisina, Sengadji, Ohirela, Karepesina. Kelima anak Laturone ini, pada saat migrasi dari Nunusaku ke Alaka, turut serta dengan keluarganya masing-masing. Anak-anak Laturone inilah, ketika di Alaka menjadi cikal-bakal lima negeri dalam kesatuan Hatuhaha Amarima yang bersifat geneologis teritorial. Sifat geneologis teritorial dari uli Hatuhaha Amarima tampak dalam nama lengkapnya, yaitu: Hatuhaha Amarima Lou Nusa. Nama ini diambil dari kata hatu berarti batu, haha artinya atas, aman (dari kata ama) berarti ayah atau negeri, rima artinya lima, lou berarti berkumpul atau bersama, dan nusa artinya pulau. Hatuhaha Amarima Lou Nusa memiliki pengertian: perkumpulan lima negeri berkumpul di atas batu pada pulau Haruku. Uli Hatuhaha Amarima adalah salah satu persekutuan adat yang terdiri dari lima negeri di Pulau Haruku yang penduduknya memeluk agama yang berbeda. Kelima aman itu adalah : 1). Aman Hatu Sima (negeri Pelauw), 2). Aman Hatu Waela (negeri Rohomoni), 3). Aman Hatu Alasi (negeri Hulaliu), 4). Aman Hatu Amen (negeri Kailolo), 5). Aman Hatu Hutui (negeri Kabauw). Uli Hatuhaha Amarima merupakan bentuk ikatan kekerabatan serta persekutuan adat, genealogis, teritorial di pulau Haruku (Uhi, 2005: 2), yang masih melestarikan nilai-nilai budaya hingga kini. Uhi (2004: 65) menyebutkan, kelima aman (negeri) yang menyatukan diri dalam uli Hatuhaha Amarima dikenal juga dengan nama: 1). Kelompok Hatu sima (batu hutan), dikenal dengan nama matasiri atau yang disebut Pelauw. 2). Kelompok Hatu Waela (batu air) yang sekarang dikenal dengan nama Rohomoni. 3). Kelompok Hatu Alasi (batu pertapa) yang disebut Hulaliu. 4). Kelompok Hatu Amen (batu salawaku atau penangkis) yang dinamakan Kailolo.5). Kelompok Hatu Hutui (batu keliling) yang dinamakan Kabauw. Seluruh sejarah Hatuhaha Amarima dituangkan dalam kapata (nyanyian rakyat), dan berbagai putusan dalam pemerintahan Hatuhaha Amarima selalu diawali dengan mosonipi (musyawarah).

Hatuhaha Amarima dianalogikan dengan tubuh manusia, antara lain: kepala sampai leher adalah Pelauw, badan sebelah kiri sampai tangan kiri adalah Rohomoni, badan sebelah kanan sampai tangan 
kanan adalah Hulaliu, pusar sampai ujung kaki kanan adalah Abauw, dan pusar sampai ujung kaki kiri adalah Kailolo. Analogi ini bermuara pada pembagian tugas dan fungsi dalam Hatuhaha Amarima, antara lain: 1) Aman Pelauw mengatur dan mengurus pemerintahan (upu kamar), yakni politik. 2) Aman Hulaliu bertindak sebagai juru 3) Aman Rohomoni mengurus adat dan agama (nana hutalane). 4) Aman Kabauw berfungsi untuk menyimpan arsip. 5) Aman Kailolo mengatur dan mengurusi masalah ekonomi atau pengatur kehidupan sesehari (ma'ahata mahaia), yakni logistik. Masyarakat Hatuhaha Amarima selalu mempertahankan tradisi Nunusaku, meskipun pada kenyataannya dapat dipengaruhi oleh unsur-unsur kebudayaan Islam yang masuk dan berkembang melalui agama Islam. Pertumbuhan dan perkembangan agama Islam di Hatuhaha Amarima tidak terlepas dari peran orang Arab dan lainnya yang datang ke pulau Haruku.

Penerimaan agama Islam sebagai agama resmi Hatuhaha Amarima didasarkan atas keinginan dan kesadaran sendiri. Hal inilah yang menjadikan agama Islam melembaga dan mengakar, serta mengambil struktur dalam masyarakat. Aman menerapkan sebagian dari budaya politik Islam dalam struktur pemerintahannya (Putuhena, 2006: 349), sehingga Hatuhaha Amarima menjadi sebuah bangsa, yakni kerajaan. Peperangan antara Hatuhaha Amarima dengan Portugis yang disebut perang Alaka I merupakan puncak dari dinamika Hatuhaha Amarima pada zaman Portugis dan menghasilkan adanya suatu perubahan yang tidak saja menyangkut bidang keagamaan, namun juga kebudayaan. Peralihan kepercayaan dari agama Islam ke Katolik, sebagaimana yang dialami Hulaliu merupakan bagian dari bukti nyata adanya dinamika perjumpaan agama dan budaya. Meskipun masyarakat Hulaliu telah memeluk agama Katolik, status dan keberadaan Hulaliu sebagai anggota Hatuhaha Amarima masih dipertahankan sampai kini. Peristiwa perang Alaka II (perang melawan Belanda) ternyata merupakan bagian yang tidak terpisahkan. Perang ini merupakan upaya masyarakat Hatuhaha Amarima menunjukkan identitas sebagai komunitas yang kuat dalam adat dan agama serta tetap mempertahankan eksistensi tersebut. Selain itu, eksistensi Hatuhaha Amarima, dalam konteks pendu- 
dukan Jepang, jelas berada dalam tekanan yang bukan diakibatkan oleh status agama Islam, melainkan oleh karena ketidaktaatan masyarakat. Hatuhaha Amarima tetap bereksistensi meskipun menghadapi kekuatan penjajahan, hingga masuk di era kemerdekaan Republik Indonesia.

Dinamika historis Hatuhaha Amarima menunjukkan adanya upaya untuk mengatasi setiap permasalahan yang dihadapi. Masyarakat Hatuhaha Amarima selalu berpikir untuk mengatasi setiap permasalahan dengan model karya budaya yang khas. Cara mengatasi konflik bersaudara di Nunusaku, penerimaan Islam di Alaka, juga perang melawan imperialisme, menunjukkan budaya Hatuhaha Amarima yang khas. Kebudayaan Hatuhaha Amarima pada kenyataannya berwujud dalam tradisi agama, adat, dan bahasa. Wujud kebudayaan tersebut selalu terkait antara satu dengan lainnya. Saat melaksanakan tradisi budaya, nampak agama, adat dan bahasa Hatuhaha selalu menjadi bagian yang turut serta. Wujud kebudayaan Hatuhaha Amarima terlihat pada tiga aspek penting, yaitu adat, agama, dan bahasa. Ketiga aspek ini menjadi utama dalam kebudayaan Hatuhaha Amarima, dan penjelasannya berkaitan dengan kosmologi Hatuhaha Amarima. Skema kosmologis Hatuhaha Amarima mengandung tiga unsur penting dari pandangan Hatuhaha Amarima tentang alam semesta dan lingkungan hidup. Ketiga unsur itu, yakni: 1) tantangan manusia di tengah alam sekitar, 2) perpaduan angka-angka, dan 3) kebersamaan manusia dengan kelompoknya. Tiga skema kosmologis Hatuhaha Amarima menampilkan sifat dialektis, yang pada umumnya, dimiliki oleh masyarakat Ambon dan Maluku Tengah. Hatuhaha Amarima awalnya menganut kepercayaan "agama asli" Hatuhaha, yang jika diteliti secara mendalam memiliki keterkaitan dengan agama Nunusaku. Agama ini muncul karena adanya suatu getaran, suatu emosi yang timbul karena memiliki rasa kesatuan sebagai sesama warga masyarakat yang memiliki rasa senasib di Alaka. Perkembangan selanjutnya, agama Islam dan Agama Kristen berada dan berkembang di tengah-tengah komunitas Hatuhaha Amarima. Agama Kristen dianut oleh masyarakat Hulaliu namun tidak dapat dikucilkan dan diabaikan dari keanggota- 
an persekutuan yang telah dibangun oleh para leluhur itu. Kesadaran ini yang membuat agama Kristen tetap secara bebas dikembangkan. Agama, pada satu sisi merupakan jurang pemisah antara masyarakat Hulaliu dengan masyarakat dari keempat negeri yang lain. Hal ini disebabkan ajaran-ajaran yang dikembangkan dalam agama Islam dan agama Kristen berbeda. Agama, pada sisi yang lain, merupakan "reserve" (cadangan) bagi keutuhan dan kelangsungan kesatuan Hatuhaha Amarima. Baik masyarakat yang beragama Kristen maupun yang beragama Islam tidak dapat menyangkal kenyataan bahwa masingmasing saling dibutuhkan bagi kelangsungan persekutuan Hatuhaha Amarima. Bahasa, dalam konteks Hatuhaha Amarima, berada dalam fungsi ganda yang memberi peran aktif bagi terciptanya kesatuan Hatuhaha Amarima yang kokoh. Fungsi ganda tersebut adalah: bahasa sebagai alat persatuan dan bahasa sebagai alat komunikasi. Kode-kode penting selalu digunakan untuk memperlancar komunikasi antaranggota masyarakat Hatuhaha Amarima. Salah satu kode (sekaligus kata sapaan) yang selalu ditemui adalah ungkapan momo yang artinya om dan kata upu yang artinya kakek. Selain itu, kode (sekaligus sapaan) untuk orang perempuan digunakan kata "ina" atau "ua", sapaan untuk ibu-ibu dan kata "mahina", sapaan untuk perempuan yang belum menikah. Mengucapkan kata momo atau upu, lebih bernilai dan lebih berharga daripada mengucapkan kata om atau tete (kakek). Begitu juga kata ina atau ua (juga mahina). Alasannya, jika kata momo atau upu diucapkan hal itu menunjukkan adanya kekerabatan atau hubungan yang erat antara orang yang menyapa dengan orang yang disapa. Kekerabatan atau hubungan tersebut adalah dalam kaitan sebagai gandong yang terjalin sejak leluhur Hatuhaha Amarima. Komunikasi dalam masyarakat Hatuhaha Amarima, secara adat, dikenal dengan tiga istilah yang hidup dalam kehidupan bermasyarakat, sebagaimana yang disebutkan oleh Uhi (2004: 127), yaitu: 1) Pasawari, yakni manusia berbicara dengan penguasa di langit (contohnya berdoa). Komunikasi dengan penguasa di langit dengan menggunakan bahasa Hatuhaha; 2) Palamana atau Patamasi, yaitu manusia berbicara dengan manusia (contohnya dalam acara adat kawin). Komunikasinya juga menggunakan bahasa Hatuhaha; 3). Patanipi, yaitu manusia berbicara dengan arwah 
(contohnya, kalau hendak melakukan acara cakalele kepala adat berbicara dengan arwah untuk minta kekuatan atau kekebalan). Tradisi komunikasi dalam bahasa Hatuhaha selalu menjadi dominan dan utama di setiap agenda kemasyarakatan dan keagamaan. Pasawari, palamana atau patamasi, dan patanipi hanya dapat terlaksana jika menggunakan bahasa Hatuhaha dalam komunikasi. Hal ini menunjukan bahwa bahasa Hatuhaha berperan penting dalam setiap kehidupan kemasyarakatan.

Konstruksi identitas budaya Hatuhaha Amarima, pada kenyataannya, menampilkan suatu perjumpaan antara adat dan agama. Agama Islam, yang diperkenalkan oleh pedagang Arab, Cina, dan suku bangsa Melayu lainnya tidak langsung diterima oleh leluhur Hatuhaha Amarima. Ada proses adaptasi ajaran, bahkan akulturasi, antara Islam dengan realitas alam, tradisi, adat, dan budaya Hatuhaha Amarima. Penyesuaian ajaran Islam dengan adat Hatuhaha Amarima dapat ditemui dalam ritual-ritual, seperti cakalele (ma'atenu), aroha, ta'alasi, dan malam 7 likur. Pattikayhatu dan Manuputty (1998: 73-76) menyebutkan tradisi-tradisi lainnya sebagai budaya Hatuhaha Amarima yang dipengaruhi oleh adat dan agama, seperti ma'alawa hinia huai, ma'anara tenu'no, dan cuci keramat. Cakalele merupakan ritual atau tarian yang menggambarkan semangat masyarakat Maluku dalam berperang melawan musuh. Tradisi aroha adalah ritual penghormatan kepada: Nabi Muhammad SAW, para leluhur, dan para wali yang membawa dan mengajarkan Islam kepada komunitas Hatuhaha Amarima. Istilah aroha berasal dari kata aroho yang berarti ke jalan roh (Rumahuru, 2012: 153). Tradisi adat dan agama lainnya, cuci keramat, atau dalam istilah masyarakat setempat disebut $t a^{\prime}$ alasi adalah suatu upacara adat, yang berhubungan dengan kepercayaan lama, yakni membersihkan atau merenovasi makam para leluhur dari suatu mata rumah atau soa (Pattikayhatu \& Manuputty, 1998: 77). Tradisi cuci keramat ini memiliki kekhasan, sebab tidak dilakukan oleh pribadi atau keluarga tertentu ke makam keluarganya. Cuci keramat dilakukan secara berkelompok, sesuai keanggotaan soa dengan sasaran makam leluhur, dan wali yang membawa agama Islam. Tradisi cuci keramat di Alaka, pada kenyataannya, tidak saja bermakna penghormatan pada leluhur, tetapi juga 
mengandung makna meneruskan semangat perjuangan bagi generasi muda. Cakalele, aroha, dan cuci keramat memiliki makna kebersamaan dan persaudaraan yang kuat dalam Hatuhaha Amarima. Jalinan relasi dan komunikasi antaranggota masyarakat Hatuhaha Amarima berlangsung dalam setiap proses ritual sampai puncak acara. Relasi dan komunikasi tersebut harus terjalin dalam suasana hati yang suci, pikiran yang bersih, dan dengan semangat kebersamaan yang tinggi. Selain itu, seluruh proses ritual dari acara cakalele, aroha, dan cuci keramat memperlihatkan adanya ikatan batin yang kuat antara masyarakat Hatuhaha Amarima dengan leluhurnya.

Hubungan persaudaraan yang kuat dalam Hatuhaha Amarima disebut maningkamu. Istilah maningkamu berarti kerahiman. Maningka$m u$, secara filosofis mengandung tiga unsur dasar, yakni: 1) sadi, artinya sesuatu yang tidak diketahui, tapi ada atau yang disebut ego; 2) wadi, berarti sesuatu yang diketahui, ada di mana-mana; 3) mani, yang artinya sesuatu yang sudah terbentuk. Ketiga unsur - sadi, wadi, dan maniinilah yang akhirnya melahirkan adanya manusia, dan memunculkan maningkamu. Artinya, terjadi perjumpaan antara "sesuatu" yang tidak diketahui, tapi ada, dengan "sesuatu" yang diketahui dan ada dimanamana, juga bersama sesuatu yang sudah terbentuk. Perjumpaan ini menghasilkan terbentuknya manusia yang berdiam di dalam rahim. Rahim merupakan tempat terbentuknya janin manusia. Rahim juga menjadi ruang bertumbuh dan berkembangnya manusia yang satu ke manusia berikutnya selama periode tertentu pada seorang perempuan. Rahim menjadi simbol persaudaraan dalam sistem kekeluargaan di Hatuhaha Amarima, yang dalam istilah orang Maluku disebut gandong, atau kandung. Maningkamu mengandung makna mempererat tali persaudaraan sebagai satu gandong, yakni lahir dari satu rahim. Maningkamu mempertegas hubungan kekeluargaan dan kekerabatan antara satu dengan yang lainnya dalam kesatuan Hatuhaha Amarima. Kekeluargaan di sini adalah keluarga-keluarga dalam matarumah yang memiliki hubungan dekat, membentuk satu kekerabatan dari keturunan ayah, dan atau ibu. Kekerabatan, dalam hal ini, adalah anggota kekerabatan dari matarumah lain atau soa lain, yang menjadi bagian dari 
kekerabatan tertentu karena hubungan perkawinan atau adanya relasi yang baik.

\section{FILSAFAT KEBUDAYAAN HATUHAHA AMARIMA}

Perkembangan pemikiran dalam analisis historis Hatuhaha Amarima, bila dipetakan dengan pandangan van Peursen, memperlihatkan adanya pola pemikiran Hatuhaha Amarima yang berkaitan dengan tahap perkembangan budaya sebagaimana disebutkan oleh van Peursen. Tahap-tahap itu tidak hanya dipandang secara historis semata, namun turut memperlihatkan suatu makna yang terkandung dalam setiap kebudayaan. Tahap itu dimulai dari pola pemikiran mitis (pra-rasio) ke alam pemikiran ontologis dan kemudian ke alam pemikiran fungsional.

Tahap pemikiran mitis, di dalam sejarah Hatuhaha Amarima, dapat dilacak dalam tiga warisan pandangan dan keyakinan yang ada pada pemikiran masyarakat Hatuhaha Amarima. Ketiga warisan dan pandangan tersebut adalah mitos Nunusaku, mitos manusia Maluku dan mitos gunung Alaka. Ketiga warisan dan pandangan ini merupakan dasar untuk memahami identitas dan realitas terdalam dari kehidupan masyarakat Maluku, khususnya Hatuhaha Amarima. Manusia Maluku selalu menempatkan Nunusaku sebagai bagian yang tidak terlepas dari eksistensinya, dan manusia Hatuhaha Amarima juga mengakui keberadaannya dalam keterhubungan dengan Alaka. Mitos Nunusaku dan Alaka adalah suatu cerita yang sangat memengaruhi persepsi dan pemahaman masyarakat Hatuhaha Amarima dalam merespons setiap tantangan kehidupan. Manusia Hatuhaha Amarima yang hidup pada zaman tersebut selalu menanggapi segala gejala kehidupan manusia maupun alam dalam perspektif mitis. Hal inilah yang memicu adanya "agama Nunusaku" atau "agama asli Hatuhaha" sebelum masuknya agama Islam. Agama-agama ini (Nunusaku dan asli Hatuhaha) muncul sebagai akibat dari kuatnya pemahaman akan mitos atau cerita tentang dunia pada alam sekitarnya.

Tahap ontologis yang disebutkan oleh van Peursen ternyata memuat suatu kenyataan pada Hatuhaha Amarima bahwa terjadi perge- 
seran dalam cara berpikir, yaitu peningkatan dalam pemikiran manusia. Perubahan pemikiran itu ditandai dengan upaya melepaskan diri manusia dari belenggu pengaruh mitis yang membuat komunitas Hatuhaha Amarima tidak bebas berkreatif. Tahap berpikir ontologis menjadi penting di dalam sejarah perkembangan Hatuhaha Amarima sebab terjadi pendewasaan dalam berpikir, yang ditandai dengan adanya kemampuan manusia Hatuhaha Amarima untuk membangun berbagai gagasan kritis dan konseptual dalam menata atau mengorganisasikan kehidupan masyarakat Hatuhaha Amarima secara sosial. Tahap ini, pada Hatuhaha Amarima, tampak dalam proses-proses pengelompokan sosial dalam bentuk $u l i, u k u$, hena, dan kerajaan. Tradisi mosonipi dan sistem pemerintahan Hatuhaha Amarima juga merupakan bagian dari cara masyarakat Hatuhaha Amarima mengembangkan pemikiran dari yang bersifat mitis ke pemikiran yang ontologis. Diterimanya Islam sebagai agama resmi Hatuhaha Amarima dan dikemudian hari Hulaliu menerima Kristen menunjukkan adanya perubahan pemikiran dari yang bersifat mitis ke ontologis. Pembentukan uli Hatuhaha Amarima dan berwujudnya Hatuhaha Amarima dalam bentuk kerajaan Islam Hatuhaha mengindikasikan adanya suatu pemikiran baru yang memberikan tempat untuk akal budi bekerja mencari pengertian dan penerangan, dengan membuat abstraksi-abstraksi dan konsepkonsep ontologis. Pada tahap ontologis, masyarakat Hatuhaha Amarima mengalami proses identifikasi akal dengan kausalitas, yaitu ketika melalui penalaran seseorang dapat menjelaskan penyebab dari segala sesuatu.

Dinamika agama dan budaya dalam kekuatan Imperialisme Barat, maupun pada zaman Jepang telah mendorong proses petumbuhan pemikiran dalam komunitas Hatuhaha Amarima menuju taraf pemikiran fungsional. Tahap pemikiran fungsional, sebagaimana yang disebutkan oleh van Peursen, ditandai dengan adanya kesadaran dan kecerdasan dalam Hatuhaha Amarima bagi upaya memfungsikan kekuatan-kekuatan yang dimiliki, untuk menciptakan kedamaian dan kesejahteraan hidup dalam tatanan sosialnya, termasuk memanfaatkan atau memfungsikan kekuatan agama dan adat untuk melakukan komunikasi dan adaptasi membangun strategi bertahan hidup (survi- 
val strategy) di dalam uli Hatuhaha Amarima. Masyarakat Hatuhaha Amarima, pada tahap fungsional, mengalami sejumlah gejala modern, sehingga manusia Hatuhaha Amarima makin menyadari pergeseranpergeseran yang sedang dialaminya. Artinya, kata fungsional dipakai sebagai semacam pegangan untuk memetakan segala hal yang berbelit-belit menjadi sederhana. Manusia Hatuhaha Amarima, dalam tahap ini, mengalami perang melawan Portugis maupun Belanda dan berbagai bentuk kekerasan masih ada, namun merupakan suatu anachronistic (bertentangan dengan zaman), sehingga terdapat upaya untuk keluar dari belenggu penjajahan (Veeger, 1985: 30). Upaya tersebut kadang harus melewati konflik, namun konflik tersebut bertujuan untuk mengakhiri peperangan.

Mengacu pada pemikiran van Peursen mengenai tahap perkembangan budaya, maka terlihat dinamika historis Hatuhaha Amarima menampilkan suatu perubahan dan perkembangan pemikiran budaya yang bersifat spiral. Sifat seperti ini mengindikasikan adanya suatu proses logika dan tingkah laku yang tidak menetap pada yang sudah ada atau masa lampau semata. Spiralitas kebudayaan Hatuhaha Amarima menunjukkan adanya gerakan yang memungkinkan telah terjadi dinamika hidup pada komunitas Hatuhaha Amarima.

Kebudayaan Hatuhaha Amarima tidak lagi memiliki kesamaan dengan kebudayaan yang ditradisikan sejak Nunusaku, melainkan merupakan kebudayaan yang lahir, berkembang, dan ditradisikan di Alaka, di pulau Haruku. Kebudayaan Hatuhaha Amarima telah membentuk pola pikir dan pola tingkah laku masyarakat Hatuhaha Amarima yang selalu menjaga relasi yang baik dengan Tuhan dan leluhur, alam semesta, dan sesama manusia. Pola kebudayaan Hatuhaha Amarima dapat dipahami, diketahui kebenarannya, dan digali nilai-nilai budayanya melalui pengungkapan aspek ontologi Hatuhaha Amarima, epistemologi Hatuhaha Amarima, dan nilai-nilai budaya Hatuhaha Amarima. Ketiga aspek tersebut disajikan sebagai upaya menempatkan kebudayaan Hatuhaha Amarima dalam perspektif filsafat kebudayaan.

Hakikat (ontologi) Hatuhaha Amarima, yakni persaudaraan. Implikasinya adalah Hatuhaha Amarima ada untuk membangun dan 
meningkatkan kehidupan sebagai orang bersaudara. Motivasi untuk membuat Hatuhaha Amarima menjadi ada dengan seluruh kebudayaan yang dimiliki, yaitu menciptakan sifat hidup kekeluargaan yang dinamis dari masa ke masa sehingga kerukunan dan perdamaian selalu dirasakan dalam kehidupan bermasyarakat. Van Peursen menegaskan hakikat kebudayaan adalah manusia dan alam. Pendapat van Peursen ini ingin menjelaskan bahwa manusia Hatuhaha Amarima sadar akan diri bersama dengan orang lain, dan semua fenomen konkret yang manusia Hatuhaha Amarima sadari (nyata atau khayalan) menghubungkan dirinya dengan yang lain, yaitu alam semesta, dan di sinilah letak persaudaraan Hatuhaha Amarima, yakni bersaudara dengan sesama manusia dan bersaudara dengan alam. Hal ini mengandung makna bahwa manusia Hatuhaha Amarima menyadari tidak ada "aku" yang murni. Semua kesadaran diri adalah kesadaran bersama yang lain. Artinya, bukan "aku" berada dulu dan menjadi manusia kemudian "aku" masuk ke dunia dan mengadakan hubungan. "aku" selalu di dalam situasi tertentu, dan selalu merupakan bagian dari dunia-dunia tertentu. Terletak makna terdalam tentang "aku" bahwa pemahaman seseorang tentang dirinya tergantung pada yang-lain, kemudian di dalam situasi dan relasi dengan yang lain seseorang mendapat kedudukan, arti dan peranan. Terlihat bahwa dalam Hatuhaha Amarima eksistensi manusia adalah ko-eksistensi, yaitu "ada-bersama", sehingga manusia Hatuhaha Amarima memiliki kesosialan yang tinggi.

Kesosialan ini disebut eksistensial, sebab terjalin di dalam eksistensi manusia. "aku" menjadi "aku" karena relasi dengan "kamu". "aku" dipanggil untuk menjadi sesama untukmu. Proses keberadaan Hatuhaha Amarima dan pola organisasinya memperlihatkan bahwa epistemologi yang muncul dari Hatuhaha Amarima adalah sebuah epistemologi tentang tanggapan manusia (masyarakat Hatuhaha) terhadap pikiran manusia yang terbentuk dari tangkapan indra terhadap objek alam dan manusia dalam keberadaan anatomi tubuh manusia. Melalui tangkapan indera itu muncul persepsi yang menimbulkan sensasi sehingga membentuk pola pikir manusia Hatuhaha Amarima untuk membangun kehidupan masyarakatnya dalam wujud satu kesatu- 
an yang tak terpisahkan antara satu dengan lainnya, yakni uli Hatuhaha Amarima. Mengetahui sesuatu, bagi manusia Hatuhaha Amarima, selalu mengandaikan adanya perbedaan antara "aku" dengan "yang lain", tetapi "yang lain" juga dapat berupa kesadaran diri sendiri. Intinya, kalimat yang cocok untuk meringkaskannya adalah pengetahuan menjalin relasi antara subjek dan objek. Hal inilah yang terlihat dalam rumusan van Peursen tentang epistemologi budaya, bahwa pengetahuan harus dipandang sebagai upaya manusia memahami sesuatu yang disadarinya, sekaligus dalam memahami itu manusia memahami dan menyadari dirinya. Rumusan van Peursen ini, setidaknya, telah menyentuh masalah pengetahuan bagi masyarakat Hatuhaha Amarima yang mengetahui dan menyadari akan keberadaan Hatuhaha Amarima ketika melihat pohon beringin dan matahari. Kebenaran atas kesadaran dan pengetahuan tersebut berdasarkan pada realitas yang nyata terlihat, bahkan ada di sekitar lingkungan tempat beradanya masyarakat Hatuhaha Amarima. Epistemologi Hatuhaha Amaraima inilah yang dengan sendirinya membentuk masyarakat untuk tetap menjaga dan mempertahankan Hatuhaha Amarima sebagai kesatuan yang utuh, meskipun telah berada di zaman yang berubah.

Nilai-nilai dalam budaya Hatuhaha Amarima sebenarnya memiliki bobot nilai yang sama dan nilai-nilai tersebut sama pentingnya, sebab semua nilai itu berasal dari Allah, Nilai Yang Tertinggi (Hadiwardoyo,1985: 6). Artinya, untuk menetapkan hierarki nilai dalam budaya Hatuhaha Amarima perlu menentukan nilai utama dari Hatuhaha Amarima. Alasannya, nilai utama menjadi acuan melahirkan nilai lainnya. Walau demikian, nilai-nilai budaya Hatuhaha Amarima berikut ini tidak dapat dilihat secara terpisah, sebab memiliki keterkaitan antara satu nilai dengan nilai lainnya. Nilai-nilai dalam budaya Hatuhaha Amarima dapat disebutkan berikut ini.

Pertama, nilai Ketuhanan dapat diukur dengan memperhatikan fakta religiusitas masyarakat Hatuhaha Amarima. Menurut van Peursen, fakta memperoleh maknanya dalam percakapan yang bersifat intersubjektif. Nilai ketuhanan, dalam perspektif adat dan agama Hatuhaha Amarima, merupakan faktor yang paling fundamental, dan mutlak. Artinya, nilai ketuhanan menjadi faktor yang kuat dalam pem- 
bentukan karakter dan aktivitas Hatuhaha Amarima. Masyarakat Hatuhaha Amarima memiliki gagasan tentang Tuhan, dan gagasan tersebut termasuk warisan paling kuno dari sejarah manusia Hatuhaha Amarima, sehingga selalu merupakan suatu kenyataan. Gagasan tentang Tuhan tidak saja didapatkan melalui pengalaman dalam keagamaan Islam atau Kristen. Gagasan tentang Tuhan sudah ada dari zaman Nunusaku dan Alaka. Mitos yang berkembang dan hidup di tengah-tengah komunitas masyarakat Hatuhaha Amarima telah menempatkan manusia Hatuhaha Amarima ada dalam keyakinan akan Tuhannya. Upu Lanite atau Opo Lastala sudah menjadi pegangan yang kuat, yang di kemudian hari ditransformasikan ke dalam ritual adat, bahkan agama. Tuhan yang dipegang sejak zaman pra-Islam dan Tuhan yang diyakini pada masa agama-agama resmi (Islam dan Kristen) adalah Tuhan yang telah membentuk persekutuan Hatuhaha Amarima. Tuhan itu pula yang selalu menjaga, memelihara, dan merahmati masyarakat Hatuhaha Amarima. Gagasan Tuhan seperti ini menjadi spirit (penggerak) bagi seluruh aktivitas Hatuhaha Amarima, sehingga selalu tergerak untuk melaksanakan berbagai macam ritual adat dan agama. Pemicu nilai ketuhanan atau nilai religius adalah estetika, yakni kekaguman akan keindahan alam semesta di Alaka. Pernyataan ini menjadi rujukan dalam melihat pertumbuhan dan perkembangan nilai ketuhanan dan religius pada konteks Hatuhaha Amarima. Nilai estetika, yang dimaksudkan di sini, bukanlah satu-satunya faktor pendorong bertumbuhnya nilai ketuhanan. Ada faktor lain yang tampak menjadi motivasi kuatnya penerapan nilai ketuhanan atau religius di Hatuhaha Amarima, yakni pengaruh mitos Alaka. Kepercayaan akan agama Nunusaku, pelaksanaan haji yang selalu berlangsung di Alaka merupakan bukti kuat bahwa faktor estetika pada gunung (Nunusaku dan Alaka) dan batu Alaka, mitos Alaka, serta sejarah Hatuhaha Amarima menjadi pemicu sikap pemujaan dan penyembahan kepada Tuhan. Sikap tersebut melahirkan nilai-nilai religius, sekaligus nilai ketuhanan dalam diri setiap manusia Hatuhaha Amarima.

Kedua, nilai Kemanusiaan merupakan prinsip dan tolok ukur yang dapat dikembangkan melalui kebenaran akan pengetahuan tentang budaya Hatuhaha Amarima, yang secara umum, lahir dari suatu 
kebudayaan yang realistis. Kebudayaan yang realistis dan empiris adalah karya manusia Hatuhaha Amarima untuk humanisme. Alasannya, seluruh kebudayaan yang diciptakan oleh manusia Hatuhaha Amarima, pada kenyataannya, ditujukan untuk keberlangsungan kehidupan manusia dan alam secara umum. Paham tentang realitas Hatuhaha Amarima, pada kenyataannya telah mempertimbangkan prinsip-prinsip kultural, dan menempatkan humanisme sebagai faktor yang penting dan utama dalam setiap upaya pengembangan pengetahuan budaya yang benar tentang Hatuhaha Amarima. Sapaan-sapaan yang relasional dalam komunitas Hatuhaha Amarima, secara nyata, mempertegas makna nilai-nilai kemanusiaan. Ucapan-ucapan, seperti momo ahone, atau ua ahone, merupakan sedikit dari sekian banyak prinsip dan nilai-nilai kemanusiaan yang hidup dan mengalir dengan sendirinya pada realitas adat, dan budaya Hatuhaha Amarima. Bahasa Hatuhaha, ternyata turut memberikan kontribusi yang sangat penting dan berarti bagi penerapan nilainilai kemanusiaan di Hatuhaha Amarima. Hanya dengan menyapa sesama anggota Hatuhaha melalui penggunaan sapaan dalam bahasa Hatuhaha mampu menurunkan intensitas amarah dan emosi yang tinggi saat konflik Maluku. Bahasa Hatuhaha mampu menghubungkan jurang pemisah, yakni agama, sekaligus menjadi "mercusuar" untuk perdamaian Maluku. Kesadaran humanis selalu muncul dalam kalangan Hatuhaha Amarima melalui Bahasa Hatuhaha, dan kesadaran tersebut yang merambat dalam mendeklarasikan perdamaian Maluku.

Inti budaya hidup orang basudara (hidup orang bersaudara) di Hatuhaha sejatinya merupakan upaya penegakan nilai-nilai kemanusiaan dan merupakan bagian dari wujud nyata etika dalam beragama dan berbudaya. Isinya seputar kebebasan manusia, dan sekitar perlakuan yang sifatnya manusiawi. Etika global, secara umum, hendak mengatakan bahwa di hadapan semua manusia, agama dan keyakinan, adat dan budaya menuntut memperlakukan manusia secara manusiawi. Artinya, setiap manusia tanpa memandang umur, jenis kelamin, ras, warna kulit, kemampuan fisik atau mental, bahasa, agama, dan status soaial memiliki martabat yang tidak dapat diganggu dan dicabut. Setiap manusia Hatuhaha Amarima, melalui budaya Hatuhaha Amari- 
ma, diharuskan untuk berperilaku dengan cara yang betul-betul manusiawi, melakukan kebaikan dan menghindari kejahatan. Alasannya, manusia Hatuhaha Amarima pada intinya memiliki akal budi dan hati nurani.

Ketiga, nilai sosialitas terlihat dari hakikat Hatuhaha Amarima. Relasi atau hubungan antaranggota Hatuhaha Amarima, jika digali dari aspek ontologi Hatuhaha Amarima, ternyata menampilkan suatu relasi "aku"-“engkau". Relasi ini, oleh van Peursen merupakan relasi antara subjek dan objek. Relasi subjek ("aku") - objek ("engkau") tersebut menempatkan setiap anggota Hatuhaha Amarima untuk selalu ada dan menjalin hubungan yang kuat dengan sesama anggota Hatuhaha Amarima. Relasi "aku"-engkau" terjadi dalam eksistensi yang utuh dan total, di mana "aku" harus memperlakukan "engkau" sebagai "engkau", bukan sebagai bagian dari "aku" (Buber, 1937: 151). "Engkau" bukan alat atau instrumen yang dapat diperalat oleh "aku". Sebaliknya, "engkau" harus diperlakukan sebagai entitas "yang ada pada dirinya sendiri" dan "ada bagi dirinya sendiri". Artinya, dalam relasi "aku"-engkau" pada komunitas Hatuhaha Amarima, "aku" Hatuhaha masuk atau menjalin relasi langsung dengan "engkau" Hatuhaha. Di dalamnya "engkau" Hatuhaha dan "aku" Hatuhaha berjumpa dalam kasih yang total, tanpa ada kebencian. "aku" Hatuhaha dan "engkau" Hatuhaha tidak hanya berdiri dalam suatu hubungan relasi, tetapi juga dalam segala ketulusan hati.

Relasi Hatuhaha Amarima, dengan sendirinya mengandung pengertian sebagai pertukaran paham. "Aku" Hatuhaha terbentuk oleh lingkunganku, sehingga dengan relasi "aku" Hatuhaha bertukar pemahaman dengan lingkunganku. Jadilah hubungan atau relasi itu sebagai pertukaran paham universal yang aktual dan nyata, dan benarbenar realistis. Tentu, dengan relasi tersebut, "aku" - engkau" Hatuhaha selalu saling membutuhkan, bahkan saling ketergantungan. Kehadiran "engkau" Hatuhaha di hadapan "aku" Hatuhaha membuat "aku" Hatuhaha sadar akan ada-ku sebagai Hatuhaha Amarima. "Engkau" Hatuhaha adalah cermin bagi "aku" Hatuhaha dalam melihat diriku sendiri. Tanpa melihat "engkau" Hatuhaha, aku" Hatuhaha akan menjadi diriku sendiri. Jalinan sosial Hatuhaha Amarima dapat 
terjadi dengan adanya relasi "aku" Hatuhaha dengan "engkau" Hatuhaha. "aku" menjadi "aku" Hatuhaha karena "engkau" Hatuhaha, dan "aku" dipanggil untuk menjadi "aku" Hatuhaha karena "engkau" Hatuhaha. Begitu juga sebaliknya, "engkau" Hatuhaha menjadi "engkau" Hatuhaha karena ada "aku" Hatuhaha.

Relasi "aku" Hatuhaha dengan "engkau" Hatuhaha merujuk pada beberapa hal, antara lain: pertama, "aku" Hatuhaha adalah salah satu negeri dari komunitas Hatuhaha Amarima, dan "kamu" Hatuhaha adalah negeri-negeri lainnya dalam Hatuhaha Amarima. Negeri, di sini, bukanlah kelompok masyarakat yang beragama tertentu, melainkan negeri-negeri dalam kesatuan Hatuhaha Amarima. Kedua, "aku" Hatuhaha adalah juga individu di dalam negeri mana saja pada komunitas Hatuhaha, dan "kamu" Hatuhaha adalah individu-individu lainnya pada negeri mana pun di Hatuhaha Amarima. Individu-individu tidak dimaksudkan hanya dalam kategori berdasarkan agama, status dalam masyarakat, marga atau soa, dan jenis kelamin. Individu adalah keseluruhan pribadi yang lahir dan memiliki garis keturunan (geneologis) sebagai anak negeri dalam Hatuhaha Amarima.

Keempat, nilai persaudaraan yang tertuang dalam filosofi maningkamu mencirikan cita, citra dan jati diri Hatuhaha Amarima turuntemurun. Maningkamu tidak sekedar mengungkap silsilah keluarga atau matarumah dalam soa. Maningkamu tidak sebatas mempertemukan anggota keluarga secara geneologis. Lebih dari itu, maningkamu, yang merupakan inti persaudaraan sejati Hatuhaha Amarima, berarti menentang ambisi dan keserakahan demi kepentingan individu atau golongan dan agamanya. Hal ini berarti, tidak mengorbankan saudara se-gandong lainnya, serta tidak merobek dan merusak tatanan hidup bersama, dan menciptakan kondisi khaos (kekacauan) dalam masyarakat.

Ada dua prinsip utama dari penegakan nilai-nilai persaudaraan sejati melalui tradisi maningkamu atau pun budaya di Hatuhaha Amarima, yaitu: manusia harus diberlakukan secara manusiawi dan apa yang ingin kamu lakukan pada dirimu, lakukanlah pada orang lain. Berdasarkan dua prinsip utama penegakan nilai persaudaraan sejati, bahkan menjadi tuntutan mendasar ini, maka ada empat hal yang men- 
jadi keharusan untuk ditaati.

Pertama, komitmen kepada budaya tanpa kekerasan dan yang menghargai hidup. Budaya tanpa kekerasan semestinya menjadi kewajiban setiap manusia, sebab kekerasaan akan mengakibatkan kematian. Hak hidup ini berlaku untuk semua manusia, hewan, dan tumbuhan.

Kedua, komitmen kepada budaya solidaritas dan tata ekonomi yang adil. Tentu budaya solidaritas harus dikembangkan karena kemiskinan banyak melanda penduduk dunia. Artinya, untuk merubahnya, sistem ekonomi Hatuhaha Amarima harus mampu menempatkan aspek keadilan yang dapat tercapai.

Ketiga, keharusan lainnya adalah komitmen kepada budaya toleransi dan hidup yang benar. Semua budaya selalu menerapkan prinsip keterbukaan dan kejujuran. Kebohongan merupakan sisi negatif yang selalu dihindar, bahkan ditiadakan dalam kehidupan masyarakat, khususnya Hatuhaha Amarima. Artinya, semua orang diwajibkan menyampaikan yang benar, sebab semua orang tidak bebas dari tanggung jawab moral untuk menyatakan kebenaran.

Keempat, terdapat keharusan yang harus ditaati, yakni komitmen kepada budaya kesamaan hak dan kemitraan laki-perempuan. Agar tercapai kemanusiaan yang seimbang antara perempuan dan laki-laki, tidak ada alternatif lain kecuali penghargaan terhadap perempuan. Hal ini meliputi kesediaan untuk menghapuskan dominasi patriarkhat, kemitraan laki-laki dan perempuan. Tentu, yang dibutuhkan untuk hal ini adalah cinta kasih, toleransi.

Kelima, nilai kerukunan dalam Kosmologi dan Budaya Hatuhaha Amarima. Dimensi kosmologi Hatuhaha Amarima memberi penekanan bahwa alam bersama realitasnya, ternyata mengeksistensikan dirinya dalam wujud manusia yang utuh pada sebuah tatanan yang dinamis. Van Peursen (2003: 155) menyadari hal tersebut, sehingga kebudayaan, menurutnya selalu berhubungan dengan manusia dan alam. Manusia mengenal kebudayaan, mengetahui refleksi, suka merenungkan diri, dan tidak dengan mudah menyerah pada alam sekitar, sehingga alam dipahami oleh manusia untuk menyusun rencana agar tidak dikuasai oleh kehendak alam. Istilah yang tepat, yaitu manusia mema- 
nusiakan alam, dan itulah kebudayaan. Pemikiran van Peursen ini menjadi dasar mengulas aspek nilai kerukunan dalam kosmologi Hatuhaha Amarima.

Kosmologi Hatuhaha Amarima memberikan penekanan yang besar terhadap upaya menjaga keharmonisan hidup, baik antara manusia dengan alam, manusia dengan Tuhan, maupun manusia dengan sesama manusia lainnya. Keharmonisan ini, tentunya, diciptakan melalui upaya menciptakan keselarasan, keseimbangan, dan kebersamaan dalam masyarakat. Upaya yang demikian hanya dapat berwujud melalui sikap menjunjung tinggi nilai-nilai kerukunan sebagai sesama manusia maupun dengan alam dan Tuhan, baik secara intern atau ekstern.

Nilai-nilai kerukunan Hatuhaha Amarima tampak dalam tradisi dan budaya yang selalu dilestarikan. Budaya-budaya, seperti cakalele atau ma'atenu, aroha, cuci keramat atau ta'alasi, dan maningkamu, pada intinya berisikan pesan menjaga dan memperkuat kerukunan hidup antara manusia Hatuhaha dengan alam, Tuhan, dan sesama manusia lainnya. Kerukunan, bagi Hatuhaha Amarima, bukan saja berarti tidak ada konflik. Kerukunan juga tidak bermakna tenang dan tentram saja (berbeda dengan masyarakat Jawa). Kerukunan, dalam tradisi Hatuhaha Amarima, berarti upaya menjaga dan mempertahankan eksistensi Hatuhaha Amarima serta memegang teguh ikatan maningkamu (persaudaraan gandong). Hal ini berarti bahwa kerukunan lebih mempertegaskan adanya upaya mengembangkan nilai-nilai hidup yang dapat menciptakan kembali keharmonisan, keselarasan, dan keseimbangan hidup.

Keenam, nilai-nilai demokrasi yang berwujud dalam budaya Mosonipi. Hatuhaha Amarima, dalam kapasitas sebagai sebuah kerajaan, mengembangkan suatu bentuk pemerintahan yang bersifat kolektif. Nilai-nilai demokrasi yang terdapat dalam prinsip budaya Hatuhaha Amarima dapat dianalisis dengan menggunakan pemikiran epistemologi budaya yang dikembangkan van Peursen, yang mengakui bahwa dalam proses pengetahuan, subjek bersifat aktif. Artinya, keaktifan subjek tidak menyembunyikan kenyataan, tetapi membuat "kenyataan menjadi nyata" (aletheia). Kegiatannya adalah "mengenal" yang 
sifatnya "mendengarkan. Mengenal bukan kenyataan yang berubah, melainkan subjek yang berubah dan diperkaya oleh pengetahuan. Mosonipi, dalam budaya Hatuhaha Amarima, memberikan penekanan pada aspek mengenal melalui cara mendengarkan.

Budaya mosonipi menjadi ruang evaluasi, sekaligus mengeluarkan pendapat, ide, dan gagasan-gagasan sebelum diputuskan untuk menjadi kebijakan pemerintahan. Hal ini berarti, tidak ada yang namanya kebijakan berdasarkan analisis dan pertimbangan pimpinan semata, melainkan yang ada hanyalah kebijakan bersama karena dimufakatkan bersama, setelah dibahas secara bersama. Pengambilan keputusan pun bukan berdasarkan voting, melainkan musyawarah mufakat. Proses pengambilan keputusan model mosonipi, pada akhirnya tidak menimbulkan perselisihan dan permusuhan yang biasanya merupakan akibat dari kesalahpahaman. Justru untuk menyatukan pemahaman, supaya tidak ada yang namanya kesalahpahaman, maka mosonipi menjadi ruang publik yang efektif.

Kandungan terdalam mosonipi adalah segala ide, pendapat dan gagasan untuk membangun Hatuhaha Amarima merupakan bagian dari suara rakyat yang harus didengar, diterima dan direspons sebagai suatu hal yang baik dalam proses bermasyarakat, maupun berbangsa. Tentu, seluruh pemikiran, pendapat, ide-ide, dan gagasan merupakan salah satu bentuk hikmat, meskipun harus diaplikasikan melalui sikap. Kekuasaan dan keputusan rakyat, melalui media budaya mosonipi, mampu menjaga dan mengembangkan sikap damai, sebab mosonipi dilakukan dalam suasana damai dan bertujuan membiasakan damai itu bagi seluruh anggota masyarakat. Saat suara rakyat, melalui pimpinan-pimpinan negerinya, diperdengarkan dalam mosonipi, dan dimusyawarahkan untuk mengambil mufakat, di situlah berwujud suatu kekuasaan rakyat, yang dalam konteks sekarang disebut demokrasi.

Aktualisasi nilai demokrasi tersebut telah menjadi pegangan secara turun-temurun dalam sistem pemerintahan adat di Hatuhaha Amarima. Meskipun Hatuhaha Amarima telah menjadi desa-desa yang berdiri sendiri, namun semangat, karakter, dan proses dan demokrasi Hatuhaha Amarima tetap dipertahankan hingga kini. Hatuhaha 
Amarima memiliki prinsip utama dalam sistem demokrasi mosonipinya, yaitu demokrasi bukanlah soal suara terbanyak. Demokrasi bukan terletak pada mayoritas pendukung. Demokrasi "mosonipi" Hatuhaha Amarima adalah mendudukkan persoalan, menemukan solusi, dan mengambil kebijakan.

Demokrasi ini menempatkan musyawarah di atas segalanya. Musyawarah dalam demokrasi Hatuhaha Amarima bukanlah pemaksaan kehendak, tetapi keterbukaan isi hati, dan penyampaian ide serta gagasan pemikiran. Nilai-nilai demokrasi Hatuhaha Amarima ini tentu disandarkan pada nilai-nilai dasar dan universal, yaitu nilai-nilai etika. Nilai etika tersebut tampak pada proses mosonipi, yang di dalamnya terdapat penghormatan dan penghargaan terhadap setiap pemikiran yang disampaikan dalam musyawarah. Nilai etika lainnya adalah kawan tetap menjadi kawan, adik dan kakak tetap bersaudara, sehingga tidak ada yang namanya lawan dalam seluruh proses demokrasi Hatuhaha Amarima; tidak ada permusuhan antara adik dan kakak; tidak ada sogok-menyogok dalam setiap praktek berdemokrasi.

Demokrasi "mosonipi" Hatuhaha Amarima ingin menghindari dampak negatif dari hasil proses berdemokrasi yang beraliran liberal. Demokrasi "mosonipi" menegakkan prinsip-prinsip persaudaraan dan kemanusiaan yang diterima sebagai hasil demokrasi, tidak seperti penerapan sistem demokrasi Barat yang menghasilkan permusuhan dan konflik. Artinya, meskipun demokrasi yang bercorak musyawarah, seperti mosonipi di Hatuhaha Amarima, memiliki kelemahan, namun dirasa masih efektif untuk diterapkan pada suatu komunitas masyarakat adat, demi persaudaraan, kemanusiaan, dan keutuhan bangsa.

Berkaitan dengan relevansi dari nilai-nilai budaya Hatuhaha Amarina terhadap keutuhan bangsa Indonesia, nilai-nilai budaya Hatuhaha Amarima (ketuhanan, kemanusiaan, sosialitas, persaudaraan, kerukunan, dan demokrasi) yang terus dilestarikan pada kenyataannya telah diaplikasikan dalam kelima sila Pancasila sekaligus sudah mengaplikasikan nilai-nilai Pancasila dalam keterlibatan keutuhan bangsa Indonesia. Relavansinya nilai-nilai budaya Hatuhaha Amarima dengan Pancasila merupakan modal untuk menjaga keutuhan bangsa 
Indonesia. Hal ini mengandung penegasan bahwa Indonesia harus bangga memiliki perbedaan dan keanekaragaman, sebab inilah yang menjadikan bangsa ini kaya akan kebudayaan. Artinya, Indonesia harus bangga dengan Maluku yang melalui komunitas masyarakat Hatuhaha Amarima, dapat merealisasikan aspek imperatif dari Pancasila, yaitu menjaga keutuhan bangsa demi persatuan Indonesia yang berketuhanan, berkemanusiaan dan beradab, berkerakyatan, dan berkeadilan bagi seluruh rakyat Indonesia.

\section{SIMPULAN}

Beberapa kesimpulan dari hasil kajian ini dapat dijelaskan berikut ini. Pertama, dinamika historis masyarakat Hatuhaha Amarima selalu menghadapi kenyataan hidup yang pahit. Dinamika historis dan wujud kebudayaan Hatuhaha Amarima mampu melahirkan suatu polarisasi budaya yang bersifat monodualisme, yakni kebudayaan yang berisikan banyak faktor. Artinya, pola kebudayaan Hatuhaha Amarima bukanlah suatu model budaya yang memilah adat dan agama, namun mensintesiskan agama dan adat menjadi satu yang disebut budaya Hatuhaha Amarima. Polarisasi kebudayaan Hatuhaha Amarima merupakan model kebudayaan yang merajut agama, adat dan bahasa dalam setiap praktek tradisi budaya yang khas Hatuhaha Amarima. Agama, adat, dan bahasa membaur dan terajut menjadi satu sehingga sulit dipisahkan, apalagi dilepaskan. Rajutan agama dan adat tersebut manghasilkan suatu kebudayaan baru yang khas Hatuhaha, yang disebut dengan kebudayaan Hatuhaha Amarima. Adat, agama, dan bahasa dipadukan menjadi suatu kekuatan yang sulit diabaikan, apalagi ditinggalkan. Semuanya menyatu dalam setiap tradisi budaya yang dilaksanakan turun-temurun. Sintesisasi adat, agama, dan bahasa tersebut semata-mata dilaksanakan untuk menjaga relasi yang baik antara manusia dengan Tuhan, manusia dengan sesama manusia, dan manusia dengan alam semesta sehingga terjalin konsep relasi "aku engkau".

Kedua, melalui uraian menyeluruh tentang Hatuhaha Amarima ditemukan bahwa persaudaraan, dalam konteks Hatuhaha Amarima, tidak saja menyangkut hubungan yang baik dan relasional antara 
manusia dengan manusia, tetapi juga menyangkut hubungan yang akrab antara manusia dengan Tuhan dan manusia dengan alam semesta. Persaudaraan ini disebut sebagai "persaudaraan sejati", yakni persaudaraan yang tidak saja menjaga hubungan baik antara manusia dengan manusia, tetapi juga hubungan baik antara manusia dengan alam semesta dan manusia dengan Tuhan atau leluhur. Hakikat persaudaraan sejati seperti ini memunculkan karakter hidup yang selalu menjaga keutuhan hidup bersama dalam komunitas Hatuhaha Amarima. Wujudnya melalui penerapan nilai-nilai budaya Hatuhaha Amarima, seperti nilai ketuhanan, kemanusiaan, persaudaraan, sosialitas, kerukunan, dan demokrasi.

Ketiga, kebudayaan Hatuhaha Amarima tidak saja mengandung nilai-nilai hidup masyarakat yang bermanfaat bagi kepentingan Hatuhaha Amarima dan masyarakat luas, yang diaktualisasikan melalui ritual-ritual tradisi adat, agama, dan budaya. Hakikat persaudaraan yang terjalin lagi di tengah suasana konflik Maluku yang masih memanas memberikan signifikansi penting untuk perdamaian Maluku dan keutuhan bangsa Indonesia. Relevansi penerapan nilai-nilai budaya Hatuhaha Amarima bagi kemanusiaan dan perdamaian Maluku telah menginspirasikan pemerintah untuk menindak-lanjuti perdamaian tersebut.

\section{DAFTAR PUSTAKA}

Bartels, Dieter, 1994, In de Schaduw van de Berg Nunusaku, Landelick Steunpunt Edukatie Molukkoes, Utrecht

Buber, Martin, 1937, I and Thou, translated by Ronald Gregor Smith, T. \& T. Clark, 38 George Street, Edinburgh.

Hadiwardoyo, AL Purwa, 1985, "Nilai-Nilai Kemanusiaan dan Hikmat bagi Pendidikan£, Pidato Dies disampaikan pada Peringatan Dies Natalis XXX IKIP Sanata Dharma 26 Oktober 1985, Yogyakarta.

Pattikayhatu, J.A., dan Manuputty, M., 1998, Sejarah Lokal Mollucas: Uli Hatuhaha, Departemen Pendidikan dan Kebudayaan, Dirjen Kebudayaan Direktorat Sejarah dan Nilai Tradisional, Pro- 
yek Inventarisasi dan Dokumentasi Sejarah Nasional, Ambon.

Peursen, C. A. van, 1951, Korte Inleiding In de Existentiephilosophie, Uitgeverij H.J. Paris, Amsterdam.

1972, Phenomenology and Reality, Duguesne U.P,

Pittsburg.

1974, Itu Tuhan: Beberapa Renungan Mengenai Arti

Kata Tuhan, diterjemahkan oleh Dick Hartoko, dari buku "Hij is Het Weer", Yayasan Kanisius, Yogyakarta.

1975, "Teori Pengetahuan", materi kuliah, disusun oleh P.de Blot.

1979, “Roh dan Kebudayaan”, dalam Basis: Majalah Kebudayaan Umum, edisi Juli 1979 XXVIII-10, Yayasan B.P. Basis, Yogyakarta.

1980, Orientasi di Alam Filsafat, diterjemahkan oleh Dick Hartoko dari "Filosofische Orientatie", PT. Gramedia, Jakarta.

1985, Susunan Ilmu Pengetahuan: Sebuah Pengentar Filsafat Ilmu, diterjemahkan oleh J. Drost, dari "De Opbouw van de Wetenschap een inleiding in de wetenschapsleer", PT. Gramedia, Jakarta.

1987, "Gospel and Culture: Experience and Conceptualization", dalam The Ecumenical Review, Index Volume 39, World Council of Churches.

1988, Strategi Kebudayaan, diterjemahkan oleh Dick Hartoko, dari buku "Cultuur In Stroomversnelling" Kanisius, Yogyakarta.

1988, Tubuh Jiwa Roh: Sebuah Pengantar dalam Filsafat Manusia, diterjemahkan oleh K. Bartens, dari buku "Lichaam - Ziel - Geest; Inleiding tot een Wijsgerige Antropologie", PT. BPK Gunung Mulia, Jakarta.

1990, Fakta, Nilai, Peristiwa: Tentang Hubungan Antara Ilmu Pengetahuan dan Etika, diterjemahkan oleh A. Sonny Keraf, dari buku "Facts, Values, Events", PT. Gramedia, Jakarta. 
1992, "Bahasa Penyair dan Kenyataan", dalam

Tantangan Kemanusiaan Universal: Antologi Filsafat, Budaya, Sejarah-Politik, dan Sastra, editor: G. Moedjanto, B. Rahmanto, dan J. Sudarminta, Kanisius, Yogyakarta.

1994, Na Het Postmodernisme: van Metafysica tot Filosofisch Surrealisme, Kok Agora, Kampen.

2003, Menjadi Filsuf: Suatu Pendorong ke Arah Berfilsafat Sendiri, diterjemahkan oleh Fitra Salam, dari buku "Wegwijs in de Wijsbegeerte: Een Aansporing tot Zelf Filosoferen", CV. Qalam, Yogyakarta. tanpa tahun, Fenomenologie en analytische filosofie, W. De Haan-Hilversum/J.M. Meulenhoff, Amsterdam. tanpa tahun, "Berpikir Secara Kefilsafatan; Bab V

- Filsafat Manusia", diterjemahkan oleh Soejono Soemargono, dkk dari buku "Wijsgerige Anthropologie", Fakultas Filsafat UGM, Yogyakarta (Tidak Diperdagangkan).

Putuhena, M. Shaleh, 2006, “Interaksi Islam dan Budaya di Mollucas: Perspektif Historis dan Religio-Politik", dalam Menjadi Indonesia: 13 Abad Eksistensi Islam di Bumi Nusantara, editor: Komarudin Hidayat dan Ahmad Gaus AF, Kerja sama Penerbit Mizan dan Yayasan Festival Istiqlal, Jakarta.

Ralahalu, K.A. dan Lokollo, J.E., 2011, Cita Budaya Mollucas dalam Pola Pemahaman Sistemik, Lembaga Kebudayaan Daerah Mollucas dengan Kolaborasi Pemerintah Provinsi Mollucas, Ambon.

Rumahuru, Yance Zadrak, 2012, "Islam Syariah dan Islam Adat: Konstruksi Identitas Keagamaan dan Perubahan Sosial di Kalangan Komunitas Muslim Hatuhaha di Negeri Pelauw", Disertasi, Sekolah Pascasarjana Universitas Gadjah Mada, Yogyakarta.

Sztompka, P., 2008, Sosiologi Perubahan Sosial, Diindonesiakan oleh Alimandan, Prenada, Jakarta.

Tauern, Odo Deodatus, 1918, Patasiwa und Patalima: Dom Molukkeneiland Seran und Seinen Bewohnern Ein Beitrag dur Delforfunde, 
Derlag Leipzig.

Uhi, Jannes A., 2004, “Hatuhaha Amarima Lou Nusa : Suatu Kajian Sosio-Historis untuk Membangun Teologi Pluralistis yang Kontekstual", Tesis, Program Pascasarjana Teologi Agama dan Kebudayaan, UKIM Ambon.

Veeger, K.J., 1985, Realitas Sosial: Refleksi Filsafat Sosial Atas Hubungan Individu-Masyarakat dalam Cakrawala Sejarah Sosiologi, PT. Gramedia, Jakarta.

Watloly, Aholiab, 2012, “Memperkuat Falsafah Hidop Orang Basudara", dalam Berlayar dalam Ombak Berkarya bagi Negeri: Pemikiran Anak Negeri untuk Mollucas, (buku Karel Albert Ralahalu), editor: Abidin Wakano dkk, Ralahalu Institut, Ambon. 